Florida International University FIU Digital Commons

7-26-1993

\title{
Reasonable accommodation under the Americans with Disabilities Act of 1990
}

Jodi B. Dell

Florida International University

DOI: $10.25148 /$ etd.FI14062237

Follow this and additional works at: https:// digitalcommons.fiu.edu/etd

Part of the Psychology Commons

\section{Recommended Citation}

Dell, Jodi B., "Reasonable accommodation under the Americans with Disabilities Act of 1990" (1993). FIU Electronic Theses and Dissertations. 2767.

https://digitalcommons.fiu.edu/etd/2767 


\begin{abstract}
OF THE THESIS
Reasonable Accommodation Under the Americans with Disabilities Act of 1990
\end{abstract}

by

Jodi B. Dell

Florida International University, 1993

Miami, Florida

Professor Scott L. Fraser, Major Professor

\begin{abstract}
The Americans With Disabilities Act (ADA) of 1990 requires that employers provide "reasonable accommodations" for qualified individuals who have a disability, provided that doing so does not result in "undue hardship". There are several guidelines that employers have been given to evaluate the reasonableness of job accommodations. Unfortunately, these guidelines have been criticized as being vague and ambiguous.

Specific factors considered when determining whether or not to grant an accommodation under the ADA have yet to be examined in psychological research. The current study
\end{abstract}


evaluated the impact of cost of accommodations, position level of the employee, and attitudes of raters for their effects on judgements of the reasonableness of requests and on subjects' likelihood of honoring requests. Results showed that accommodations were rated as more reasonable and were recommended to be honored more often for higher level positions than for lower level positions. Measures of attitudes toward disabled persons, both in general and in the workplace, did not have many significant correlations with the dependent measures. Implications of the findings and ideas for future research are discussed. 
FLORIDA INTERNATIONAL UNIVERSITY

Miami, Florida

Reasonable Accommodation Under the Americans with Disabilities Act of 1990

A thesis submitted in partial satisfaction of the requirements for the degree of Master of Science in Psychology

by

Jodi B. Dell 
Intentionally left blank. 
To Professors: Scott L. Fraser, Ph.D

$$
\begin{aligned}
& \text { Brian Cutler, Ph.D } \\
& \text { Juan Sanchez, Ph.D }
\end{aligned}
$$

This thesis, having been approved in respect to form and mechanical execution, is referred to you for judgement upon its substantial merit.

Dean Arthur w. Herriott College of Arts and Sciences

The thesis of Jodi B. Dell is approved.

Brian Cutler

Juan Sanchez

Scott Fraser, Major Professor

Date of Examination: July 26, 1993

Dean Richard Campbell

Division of Graduate studies

Florida International University, 1992 
I hereby dedicate my research to the 53 million Americans estimated to have some form of disability and who were the inspiration behind the Americans with Disabilities Act of 1990. May this act provide you with the vehicle necessary to seek and gain successful employment. 
First, I would like to take this opportunity to acknowledge my thesis chairman, Dr. Scott Fraser, for his continued support and assistance. I would also like to thank the members of my committee, Dr. Juan Sanchez and Dr. Brian Cutler. It was an honor and a privilege to have you serve as my committee. I would additionally like to acknowledge the faculty and staff of the Department of Psychology. My experience with this department during my graduate (and undergraduate) work has been very rewarding.

I would like to acknowledge the participating organizations, Royal Caribbean Cruises, Ltd., and H.R. Ross \& Associates, for allowing me to conduct research at their organization. I would also like to thank all the participants for this study.

I would like to thank my parents, Marin and Herbert Dell, for their continued love, encouragement, support, and understanding. I also want to acknowledge my sister (Jamie), brother (Scott), grandmother (Ann), Susan Shone, Lorraine Mitzner, and my friends, Dr. T. Bailey, Ph.D., Risa Caiola and Michelle Fredj. Thank you for your support and encouragement. 
LIST OF

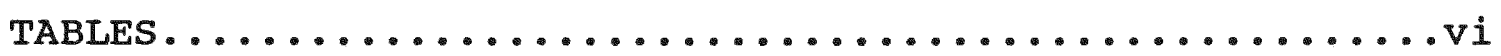

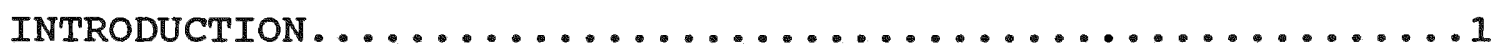

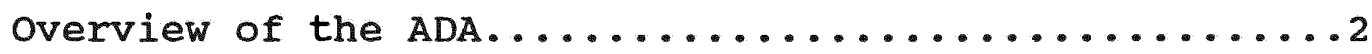

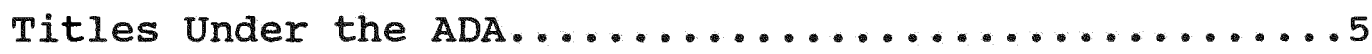

'Undue Hardship' and 'Reasonable Accommodation' under

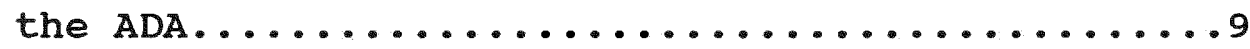

Compliance versus Non-compliance...............1

Employer's Concern About Hiring the Disabled........13

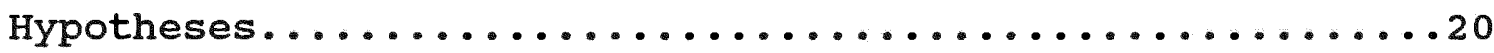

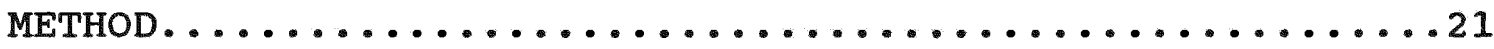

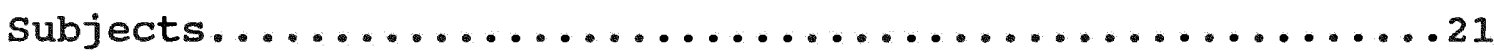

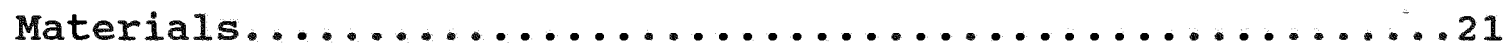

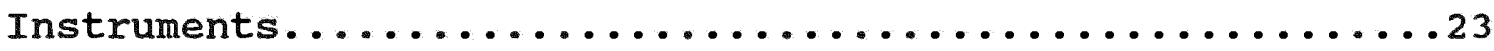

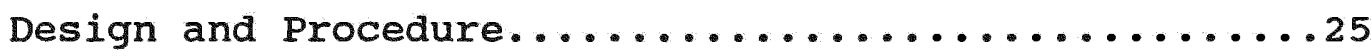

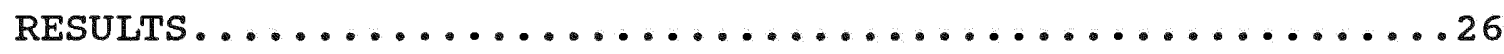

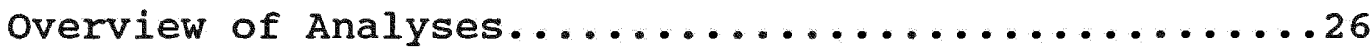

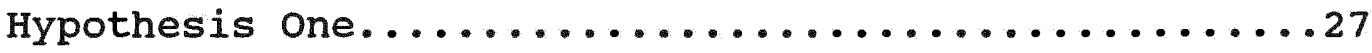

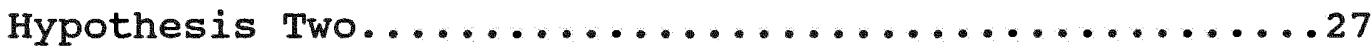

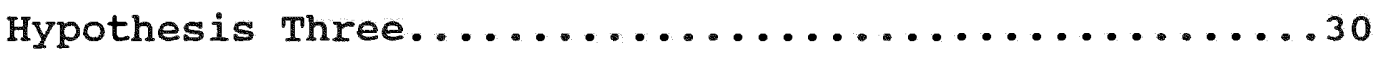

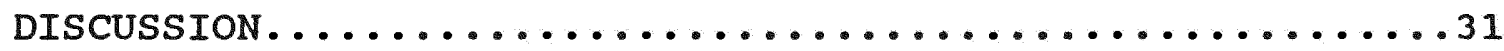

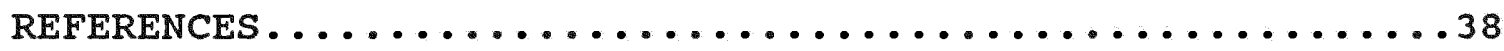

APPENDICES................................. 54 


\section{Tables}

TITLE

PAGE

1. ANOVA Results for Dependent Variables............45

2. Cell Means for the Main Effects of Position Level on "Reasonableness" Ratings and on "Honor Request"

Ratings..............................

3. Cell Means for the Two-way Interaction Between Position Level and Disability Type on the "Reasonableness of Accommodations" Scale.........47

4. Cell Means for the Two-way Interaction Between Position Level and Disability Type on the "Honor Accommodation" scale.....................48

5. Group Means for Consideration of Disability Type When Evaluating an Accommodation Request........49

6. Mean Responses for Accommodation Estimates.........50

7. Reliability of the Four EPDQ Scales and of the SADP

8. Correlations Between EPDQ Scales and other Variables

9. Frequency of Primary Factors Used to Determine Reasonableness of Accommodations..............53 


\section{Reasonable Accommodation Under}

The Americans With Disabilities Act of 1990

The Americans with Disabilities Act (ADA) was enacted

on July 26, 1990. The ADA insures full equality for individuals with disabilities similar to the protection afforded on the basis of race, sex, color, national origin, and religion by the Civil Rights Act of 1964. The ADA prohibits discrimination based on a disability in private sector employment, state and local government activities, public accommodations, services such as transportation, and telecommunications relay services (ADA, 1990).

The ADA has been regarded by legal and professional analysts as the most significant civil rights legislation to be enacted within the past twenty-five years since the civil Rights Act of 1964 (Thornburgh, 1989). The ADA was introduced as a result of congressional research findings that some forty-three million Americans have some type of disability, mental or physical (Americans with Disabilities Act, 1990). Additionally, as the population as a whole grows older, the number of Americans with a disability increases (Susser, 1990).

The present study primarily attempted to measure factors which may affect assessments of the reasonableness of accommodations for disabilities. Given the ADA's recent passage, there are no studies examining which factors 
employers might consider when determining whether or not an accommodation is reasonable. In the research described below, cost of accommodations and the Position Level of the requestor were manipulated. These factors were selected based on the theory, described below, that judgements of "reasonableness" are likely to be made on an economic basis. In addition, the relation of attitudes toward those with disabilities to judgments of reasonableness was investigated in light of conclusions from previous research (e.g., Colorez \& Geist, 1987).

Overview of the ADA

Discrimination against disabled individuals was identified by Congress in the following areas: employment, transportation, public accommodation, voting, housing, institutionalization, communication, recreation, health services, and access to public services (Susser, 1990). Congressional studies have concluded that the disabled population, as a whole, hold inferior societal status on social, vocational, economic, and educational levels (ADA, 1990). Individuals who have experienced discrimination based on a disability have had virtually no previous legal avenues to pursue.

The term "employer" refers to a person engaged in industry affecting commerce who employ 15 or more employees for 20 or more calendar weeks in the preceding or current 
calendar year (ADA, 1990). Exempt from ADA legislation are those corporations wholly owned by the US government, an Indian Tribe or bona fide private membership clubs exempt from taxation under the Internal Revenue Code of 1986, section 501-C (ADA, 1990).

The Americans with Disabilities Act (ADA) prohibits employers from discriminating against qualified individuals with disabilities on the grounds of their disabilities. An individual is qualified, under the $A D A$, if he or she can perform the essential functions of the job, with or without a reasonable accommodation (Shaller, 1991). Essential job functions are determined by each prospective employer. Furthermore, if the essential job functions have been documented by the employer prior to advertising or interviewing applicants for the position, these documents served as evidence of the job functions deemed essential (ADA, 1990).

There are numerous impairments which could label an individual as "disabled". Some impairments, however, are not "disabling" to all individuals (Lindsay, 1989-90). "Disability" under the ADA is likened to the definition of "individual handicaps" under the Rehabilitation Act of 1973. The term Disability is used to describe a physical or mental impairment that substantially limits one or more of the major life activities of the individual, a record of such an 
impairment, or the possession of such an impairment (ADA, 1990). Congress intended to cover those impairments under the ADA that would substantially limit one's major life activities such as performing manual tasks, seeing, walking, speaking, hearing, breathing, or partaking in community activities (Susser, 1990).

Physical impairments cover any physiological condition or anatomical loss resulting in a partial or complete loss of any of the following bodily functions: neurological, respiratory (including speech organs), endocrine, skin, digestive, reproductive, etc. (Susser, 1990). Mental impairments covered under the ADA include any psychological or mental disorder such as organic brain syndrome, specific learning disabilities, emotional or mental illness, or mental retardation (Susser, 1990).

"Record of impairment," under the term disability, is intended to protect individuals who are not currently disabled, but have been in the past. To be protected under the ADA, past experience must satisfy the condition of substantially limiting a major life activity. Disabilities which fall under this category are, for example, a history of heart disease, cancer, mental or psychological illnesses (Susser, 1990).

Individuals who have an impairment covered by the ADA are considered to be disabled even though their major life 
activities might not be significantly limited. Thus they may be regarded by their employer as having job-relevant limitations to their capabilities. Additionally, this category includes individuals with disabilities that provoke "negative reactions" from others, such as skin diseases or physical deformities.

An example of persons regarded as having an impairment can be found in the United states supreme court case, school Board of Nassau County V. Arline (1987). The court decided that it was discriminatory if one's ability to work was hindered by the fear of a perceived disability by employers, coworkers, customers, etc. (Susser, 1990). An example of such a perceived disability is the HIV viruses. Titles under the ADA 1990

There are five titles categorized under the ADA. The current study pertains to private sector employers, and this discussion therefore focuses on Title 1, employment and Title 3, public accommodations. These Titles are of most concern to private sector companies/organizations.

Title 1, Employment, provides that qualified individuals with a disability shall not be discriminated against based on their disabilities in any of the following procedures: job application, hiring, discharge, promotion of employees, employee compensation, job training and other conditions of employment (ADA, 1990). Under the Act, 
employers are required to reasonably accommodate the disabilities of an applicant/employee unless such an accommodation would result in an undue hardship for the employer (ADA, 1990).

For the first two years after the ADA was enacted, pertained only to those employers with 25 or more employees. Congress decided to phase in the scope of the law over two years in order to impose the immediate burden on larger companies, presumably more equipped to make accommodations. The "phase-in" approach allowed for clarification of the law and allowed for regulations and technical support programs to be created (Thornburgh, 1989).

Title 1 prohibits employers from conducting preemployment medical examinations to expose a disability or to determine the severity of one, unless the examination is used to assess job-related functions (ADA, 1990). Employers may require medical examinations according to the following conditions: after the applicant has been offered a job and before the starting date of the particular job; all applicants undergo the medical examination; the examination is voluntary; records of medical examinations are kept on separate forms and confidential. Furthermore, medical examination data should only be revealed to staff for safety precautions and for necessary medical treatment (ADA, 1990). Another major provision of the employment title regards 
individuals with infectious and communicable diseases which can be transmitted through the handling of food. The law allows for an employer to reassign an employee with such a disability to another position which does not involve the handling of food. The secretary of Health and Human Services is responsible for publishing a list of those diseases which shall be considered as infectious and communicable through the handling of food for the purposes of this act (ADA, 1990). Furthermore, these diseases can not be eliminated by any reasonable accommodation made by an employer. This list was due no later than January of 1993. Exempt from ADA protection are qualified individuals who currently use illegal drugs or alcohol. However, the Act does protect individuals who have sought treatment for drug or alcohol problems. Similarly, individuals who are currently involved in a rehabilitation program are also covered under the ADA.

Enforcement of ADA compliance is, in part, the responsibility of the Equal Employment Opportunity Commission (EEOC). The regulations, which were made public on January 26, 1991, are intended to provide more explicit definitions of terms which have been considered vague and ambiguous by business and legal analysts (Mckee, 1990; Susser, 1990). Terms such as "reasonable accommodation" and "undue hardship" are particularly unclear and troubling for 
the business community.

Remedies available to individuals under Title 1 Employment allow for private lawsuits and for filing formal complaints with the EEOC. Private lawsuits also allow reasonable accommodation and undue hardship to be determined on a case-by-case basis. Undue hardship is based on the company's size, financial resources, and facilities (McKee, 1990).

Title III of the ADA concerns Public Accommodations. This is an important title for private-sector employees since it requires that all public accommodations, such as hotels, restaurants, libraries, hospitals, and services provide equal access for all disabled persons (ADA, 1990). The ADA requires that by January 26, 1992, all physical barriers are to be removed from places of public accommodation unless they are not readily achievable.

"Readily achievable" is defined as accomplishable without great difficulty or expense (ADA, 1990). If such barrier removals are not readily achievable, alternate accommodations must be offered. An example would be if a facility is under construction, an accessible path for disabled persons to areas such as the bathrooms, telephones, etc., would need to be created (Kelly \& Aalberts, 1990). Another provision of the Public Accommodation title regards public transportation by private entities. All 
buses and vans (with capacity for transporting eight or more passengers) must be readily accessible to the disabled. If they are not accessible, an alternate but equal service must be provided for disabled travelers (ADA, 1990). "Undue Hardship" and "Reasonable Accommodation" Under the ADA

In the ADA, "undue hardship" is defined as an action requiring significant difficulty or expense. Factors considered when determining if an accommodation would impose an undue hardship are overall size of the business; number of employees; nature of the business (work-force composition and structure); and the cost and nature of the accommodation (McKee, 1990). Undue hardship is determined on a case-bycase basis.

"Reasonable accommodation" is vague and troubling by definition and purposely by design. In essence, the parameters of the reasonable accommodation clause are unknown, and business owners are therefore unsure as to compliance demands (Shaller, 1990). A proposal for an accommodation cost of up to ten percent of the requestors' annual salary, which would numerically represent "reasonable," was intentionally omitted from the original bill (Mckee, 1990).

Shaller (1990) points out that reasonable accommodation has never been defined in the act. Examples of what 
constitutes a reasonable accommodation are offered, however, each organization, disability, and applicant are different. The statute provides no clear specification as to the extent of the employee's obligation to provide an accommodation.

Examples of accommodations cited in the Act are the

following: (1) Making existing facilities readily accessible to and usable by individuals with disabilities; and (2) allowing for job restructuring, modification of work schedules from full-time to part-time, acquisition of special equipment or modification of existing equipment, and the provision of qualified readers or interpreters (such as supplying a reader for blind applicants, Shaller, 1990).

Previous cases regarding accommodations by employers which arose under the Rehabilitation Act of 1973 offer some guidance in predicting courts decisions. For example, in Wallace V. Veterans Administration (1988), an employer was found liable for not reassigning "nonessential" job functions as part of an accommodation. Wallace, a VA nurse, could return to work provided she not be made responsible for injecting narcotics. Her employer, the VA, stated that she would therefore not be able to perform the full range of job duties. At the trial, the VA was unable to prove that the limitation would significantly impact on the nature of its operations and ruled in favor of Wallace. Another example of the courts' interpretation of 
reasonable accommodation is in Foods. Inc. V. Iowa Civil Rights Commission (1982). In this case, the employer was required to provide an accommodation for an epileptic cafeteria worker. The employer, Foods Inc., was unable to show that an undue hardship would result from reassigning job duties of "occasionally operating heavy machinery". Employers must be able to prove that such job restructuring would significantly limit the employee's job functions and responsibilities to be warranted as undue hardship.

In Treadwell V. Alexander (1983), the courts ruled that an employer is not required to hire another employee to carry out the essential job functions of the disabled employee. In this case, the Army Corps of Engineers was requested to hire another park technician to perform several of the disabled employee's job functions whose disability was a serious heart condition. The court ruled that such doubling up on employees constituted an undue hardship and was therefore not required.

Compliance versus Non-compliance

Currently, under the Civil Rights Act of 1964, remedies afforded to discriminated parties are limited to back pay and job reinstatement (ADA, 1991). The ADA (1990) significantly broadens remedies to include jury trials, with potential for unlimited punitive and compensatory damages (Mckee, 1990). The potential costs for compliance with the 
$A D A$ in order to avoid lawsuit are high.

As indicated by the amount of media attention the ADA (1990) has received since it was signed into law, it is apparent that the business and legal community are highly concerned as well as confused with the ADA requirements (Shaller, 1991; Mckee, 1990). Small business owners and large corporations are unsure as to the expense and level of difficulty they are required to endure in order to satisfy the ADA's requirements. The costs for structural compliance for accessibility and for providing equal benefits are relatively clear. However, the anticipated total costs for accommodations pose major concerns for employers (McKee, 1990). Although the Act provides examples of what may constitute a "reasonable accommodation", it does not provide a definitive definition of this term for employers to use in all situations. Similarly, "undue hardship" is defined as an action requiring significant difficulty or expense and the Act describes factors to be considered when evaluating undue hardship organizational size, facilities, and budget (McKee, 1990; Susser, 1990).

still, the costs for compliance with $A D A$ regulations are not as high and potentially destructive to organizations as the cost for non-compliance when considering potential lawsuits and jury trials (McKee, 1990). According to the Job Accommodation Network (JAN), a national information and 
counseling service, 31 percent of accommodations are of no cost to the employer. Thirty-eight percent of accommodations cost between $\$ 1.00$ and $\$ 500.00$. Less than one percent of accommodations cost over $\$ 5,000.00$ as presented in Appendix $\mathbf{A}$.

It appears that "reasonable" is being viewed as an economic consideration by employers, judging from the business community's reaction. Accommodations that are most desirable to employers would thus be those that cost the least and that provide the greatest opportunities for people with disabilities. Similarly, it seemed likely that accommodations would be considered more favorably when employees/applicants are of greater value to the organization (i.e. Vice President versus Secretary). It is predicted that the greater the perceived value of the position of the employee, the more the organization will spend to provide an accommodation. This "economic" theory of how judgments of reasonableness are made was tested under Hypotheses 1 and 2; the economic factors were expressed through the cost of accommodation and position level of employee.

Employer's Concerns About Hiring the Disabled

Despite legislative attempts to create employment opportunities for qualified people with disabilities, the number of unemployed persons with disabilities is 
disproportionate relative to their representation in the population (Bowe, 1984). In 1970, Rothschild found that employers were not concerned with social problems, but rather productivity issues. Rothschild further concluded that social issues are only considered when they affect public image. In this case, companies would tend to hire "token" disabled employees to enhance their images (Rothschild, 1970).

Some of the most difficult barriers disabled individuals have to overcome are employers' attitudes toward hiring disabled persons. Research has shown that disabled people as a group are perceived negatively by the general population (Bowe, 1980; Cowen, Underberg \& Verillo, 1958; Florian, 1958; Kagen, 1959). Many employers fail or hesitate to offer disabled persons employment despite the evidence which suggests that the job-performance of disabled persons tends to be at least equal to that of non-disabled coworkers (Goodyear \& Stude, 1975; Hartlage, Roland \& Taraba, 1973).

Some of the major concerns employers have regarding the disabled are summarized in a review article by Greenwood and Johnson (1987). Their summary spans over four decades of research and over 90 articles regarding employers' attitudes toward hiring disabled workers. The following are some concerns which have either directly or indirectly 
contributed to the discrimination against disabled persons in employment.

Performance of workers with disabilities, or productivity, was a major concern of employers (Greenwood \& Johnson, 1987). This appears to be an unwarranted concern since research consistently supports quality performance by disabled employees. Investigations where employers have had direct contact with workers have consistently shown positive results (Bauman \& Yoder, 1965; Bressler \& Lacy, 1980; Roessler \& Bolton, 1984).

Another unsupported concern employers appear to have is that disabled employees have a higher rate of absenteeism than non-disabled employees. Attendance of disabled employees has been found to be equal if not better than the attendance of non-disabled employees (Bureau of Labor Statistics, 1948; du Pont, 1973, 1982; Greer, 1957). Recent studies show that employers are more concerned with absenteeism among disabled employees with chronic health conditions as opposed to more stable disabilities (Mithuag, 1980; Williams, 1972). This is due to the fact that chronic health conditions may require more periodic, medical related absences as opposed to controlled, predictable care.

Employee stability is another concern for employers according to Greenwood and Johnson (1987). Early studies concluded that ex-mental patients changed their jobs several 
times (Landy \& Griffith, 1958; Margolin, 1961). For other types of disabilities, such as blindness and physical handicaps, stability has been reported as very characteristic of disabled employees (Bauman \& Yoder, 1965; Simon, 1963).

Prior research on the integration of disabled employees into the work-force has yielded mixed results. Studies on emotional disabilities reveal that employers anticipate problems between disabled employees and non-disabled employees (Farina \& Felner, 1973; Hartlage \& Taraba, 1971). other studies concluded no major concern (Berkeley Planning Associates, 1982; Mithaug, 1980).

Research on work-force integration of people with physical handicaps is also inconclusive (Hartlage \& Roland, 1971; Phillips, 1975; Wacker, 1976). Williams (1972) concluded that concerns were held by employers for blind and deaf employees, whereas studies by Goodyear and stude (1975) reported no major concerns for these disabilities. Overall, however, employers appear to be concerned about integrating disabled persons into a primarily non-disabled work environment, especially for emotional disabilities with the exception being for blindness and deafness. Colorez and Geist (1987) concluded that negative or positive attitudes towards disabled individuals influenced subsequent behavior when interacting with them. Colorez and Geist 
(1987) describe these attitudes as prejudices which resulted in the unequal treatment of people based on their disabilities.

Employers generally expect employees with psychiatric disabilities to require more supervision than non-disabled employees (Bolanovich \& Rasmussen, 1968; Hartlage, 1963; williams, 1972). The assumption has been that workers who had more problems would demand greater structured supervision. For physical disabilities, some studies reported that employers did not expect disabled workers to require greater supervision (Bauman \& Yoder, 1965; Schletzer et al., 1961).

overall, disabilities continue to raise a red flag and pose major concerns for employers, despite the research and case studies which favorably support disabled workers as employees. Attitudinal barriers of employers toward the disabled population may pose a greater obstacle in employment opportunities than will structural barriers. similarly, requiring employers to provide a "reasonable accommodation" may open doors previously closed to qualified individuals with disabilities. Unfortunately, negative attitudes are still likely to be held by both managers and non-disabled co-workers (Greenwood \& Johnson, 1987). Accordingly the last hypothesis to be investigated was that people who had more positive attitudes toward the disabled, 
both in general and in the workplace, would be more likely to consider requests for accommodations to be reasonable and to grant them.

As previously stated, the present study was conducted to evaluate the impact of cost of accommodation, Position Level of employee, and general attitudes toward people with disabilities on judgments of accommodations. The effect that Type of disability has on judgments of accommodations was not under investigation. For research purposes, however, the use of more than one disability was deemed necessary to create the experimental scenarios.

Mithaug (1980) and Combs and Omvig (1986) concluded that physical disabilities were generally easier to accommodate by employers than were mental disabilities, with the exception of deafness or blindness. On a five-point scale $(1=$ cannot accommodate and $5=$ can easily accommodate), the mean ratings for deafness and blindness were 2.91 and 1.41 respectively (Combs \& Omvig, 1986). For this study, two types of disabilities which would present equivalent levels of difficulty for accommodations and that were in the same disability category (physical versus mental) were selected. Deafness and blindness met these requirements, and both were given low ratings for "employability" by human resources specialists (Combs \& Omvig, 1986). In further attempts to establish similarities 
between these two disabilities, they were presented to subjects in the experimental scenarios as "hearing impaired" or "vision impaired". The rationale was that less extreme versions of these disabilities would increase the likelihood that subjects would equate them.

Most of the data was collected in organizations containing fifteen or more employees. This ensured that most subjects worked in settings covered by the ADA. There are two reasons for collecting most of the data in the field. First, employees are directly affected by the integration of disabled persons in the work-force. Many employees will be forced to change job schedules, help fellow disabled co-workers in job-restructuring or reassignment accommodations, read and interpret materials for disabled applicants or co-workers, etc. This may create negative responses or feelings of inequity by non-disabled employees.

Second, previous research indicates that behaviors towards disabled individuals are affected by their attitudes toward individuals with disabilities (Kokaska \& Maslow, 1986). Employee attitudes are extremely important when considering the anticipated integration of disabled persons resulting from the ADA 1990. The goals of this research made an organizational field setting the most appropriate and representative venue for this research. 


\section{Hypotheses}

In summary, three hypotheses were tested in the study to be described below:

1. Cost of accommodation was expected to be significantly related to ratings on the "reasonable" scale and on the "honor" scale. The researchers expected to find lower Costs for accommodations to be perceived as more reasonable and more likely to be honored than would higher costs. This hypothesis is based on the "economic" theory of Reasonable Accommodation described above.

2. Position level (status) was expected to be significantly related to ratings on the "reasonable" scale and on the "honor" scale. It was hypothesized that higher ratings of reasonableness of accommodations, and of decisions to honor the accommodations, would be obtained for higher status positions than for lower status positions. This hypothesis was also based on an "economic" approach to Reasonable Accommodation.

3. Finally, favorable attitudes towards disabled people were expected to have significant positive correlations with perceived reasonableness of accommodations. Research by Colorez and Geist (1987) provides the basis for this hypothesis. 
METHOD

\section{Subjects}

The sample used in this study consisted of 96 people; employees from two South Florida organizations as well as undergraduate students served as subjects. Participating companies that had a minimum of fifteen employees were selected. Contact was made with the person identified as being responsible for hiring decisions (i.e. Personnel Directors, Human Resource Managers, etc.).

The contact for each organization was informed that their organization has been selected to participate in a study conducted by an FIU Applied Psychology graduate student. If the contact was willing to meet the student, a meeting was arranged at the contact's organization. For participating in the study, each organization was offered a summary of the results of their particular organization on the Scale of Attitudes Towards Disabled Persons.

\section{Materials}

Each subject completed a Reasonable Accommodation Research Packet. The packets consisted of four case scenarios of accommodations requested by two disabled employees. The accommodations were the Pressure Sensitive Floor Mat and Voice synthesizer (for vision impairments) and the Vibrating Signal system and Telephone Amplifier (for hearing impairments). Subjects were asked to determine the 
"reasonableness" of these accommodations for two different employees (requestors), specifically a low and high level position employee, Secretary and Executive vice President of Marketing, respectively.

cost of accommodation was manipulated between subjects. There were three cost levels: Low $(\$ 110)$, Medium $(\$ 510)$, and High $(\$ 910)$. Subjects were randomly assigned to a condition.

After assessing the reasonableness of each request, subjects were asked to evaluate the cost estimates of each of the four accommodations. Four items were used to assess whether or not subjects believed that the stated cost of the accommodations were accurate. Additionally, subjects were given three general statements regarding attitudes towards accommodations. The statements were: "An organization should consider the position level of the employee with a functional impairment when determining if an accommodation should be granted"; "An organization should consider the Cost of the accommodation when determining if an accommodation should be made for an employee", and "An organization should consider the type of disability when determining if an accommodation should be made for an employee". Subjects rated each statement on a five-point scale, with anchors of 1-strongly Disagree to 5-strongly Agree. The items were included for exploratory purposes. 
Finally, each subject completed the scale of Attitudes Towards Disabled Persons (SADP) and the Employment of People with Disabilities Questionnaire (EPDQ). The SADP has 24 items that measure general attitudes towards disabled persons; the EPDQ has 40 items that are specific to the employment of people with disabilities (refer to Instruments Section).

\section{Instruments}

The Scale of Attitudes Towards Disabled Persons (Antonak, 1982) was used in this study to assess general attitudes towards disabled people. The scale is a 24-item summated rating scale, requiring respondents to rate statements concerning disabled persons on a six-point scale. The scale typically used ranges from -3 ("I disagree very much") to +3 ("I agree very much") excluding 0 . For this study, scale points were converted to include only positive numbers: +1 ("I disagree very much") to t6 ("I agree very much").

Directions for subjects taking the SADP and the response key were printed directly on the questionnaire. Examples of items include "Disabled children should not be provided with a free public education"; "Simple repetitive work is appropriate for disable people", and "Laws to prevent employers from discriminating against disabled people should be passed". 
The reliability of the SADP is reported as ranging from +.81 to +.85 for spearman-Brown corrected reliability, and Alpha coefficients range from +.88 to +.85 (Antonak \& Livneh, 1988). The SADP has been found to measure one general factor (Chan et al, 1984; Antonak, 1982, 1985).

The SADP was selected based on the reported psychometric properties and the appropriateness of the items for an employment setting. The SADP has been used widely in the measurement of attitudes toward disabled persons (e.g., Colorez \& Geist, 1987).

In addition to the SADP, a measure more specific to attitudes toward the disabled in the workplace, the Employment of People with Disabilities Questionnaire (EPDQ, Fraser \& Skipper, 1993), was used. The EPDQ includes 40 Likert-format items which are summed into four scales. EPDQ items were based on a content analysis of previous attitude scales and on a review of literature concerning attitudes of employers toward hiring and accommodating people with disabilities.

The first scale on the EPDQ, General Attitudes Toward the Disabled (GENATT), deals with stereotypes people may have toward the disabled in general. Those who score high on this scale have a favorable impression of people with disabilities and believe that they may be effective employees. The second scale, Social Responsibility 
(SOCRES), concerns beliefs about society's acceptance of people with disabilities. High scorers are likely to think that it is the responsibility of all people to accommodate and help those with disabilities. Moreover, they are likely to view specific conditions, such as AIDS or substance abuse, as legitimate disabilities. The third scale, Workforce Integration (WFINT) deals with specific reactions to working with people with disabilities. Items on this scale concern the willingness of someone to modify their own schedule or position responsibilities to accommodate someone with a disability. Finally, the organizational

Responsibility (ORGRESP) scale includes items dealing with the extent to which employers should be responsible for creating more opportunities for those with disabilities. Fraser and skipper report reliabilities ranging from .76 to .84 for the EPDQ scales.

\section{Design and Procedure}

The current study used a 3 (Cost of accommodation) $\times 2$ (Position Level) $\times 2$ (Type of disability) design. cost of accommodation was examined between subjects, while position level and type of disability were manipulated within subjects. The cell sizes for the between-subjects factor (Cost) ranged from 28 to 36 due to missing data. However, for the purposes of this study, we expected no significant difference between the two disabilities. 
Subjects were given a Research Packet to complete either at home or at the organization. Subjects were informed in the Research Packet that "the purpose of the study is to assess accommodations for jobs that will make employment more accessible for the disabled". The Research Packet took approximately twenty to thirty minutes to complete. Subjects had two days to complete and return the packet. Only the Principal Investigator had access to the data.

\section{RESULTS}

\section{Overview of Analyses}

Three-way ANOVAs treating Position level and Type of disability as within-subjects factors were used to test the first two hypothesis. It was expected that significant main effects for position level and cost of accommodation would be found, while no significant effect would exist for Type of disability. A priori contrasts between means were conducted to test the hypothesis that a) mean "reasonableness" ratings would be highest in the low-cost condition compared to the high-cost condition and that b) mean "reasonableness" ratings would be higher in the high Position Level condition than in the low Position Level condition.

Factors listed by subjects were ranked by frequency with which they were mentioned to identify the most common 
factors subjects would use to assess reasonableness (of accommodation requests). Subjects' scores on the SADP and the EPDQ were used in a regression analysis with the "reasonableness" and "honor" ratings. These regressions were computed across all experimental conditions.

\section{Hypothesis one}

The cost of accommodation did not have a significant effect on ratings of reasonableness or on subjects' willingness to honor the accommodation requests. The results of these ANOVAs are presented in Table 1.

Insert Tables 1 through 4 About Here

Hypothesis Two

Results of the ANOVAs revealed an overall significant main effect for Position Level, $\underline{F}(1,373)=16.98, \underline{p}<.001$, where requests were rated as more reasonable in the high Position Level condition than in the low Position Level condition, as seen in Table 2 .

The ANOVA also revealed that the interaction between Type of disability and Position Level was significant for ratings of the reasonableness of accommodations, $F(1,373)=$ $5.28, \underline{p}<.05$. Post-hoc contrasts (Scheffe's) showed that, overall, there was a greater difference in the reasonableness ratings for Hearing Impaired than for Vision 
Impaired ( $\mathrm{p}<.05$, means are reported in Table 3$)$. Accommodations were rated as most reasonable in the high Position Level/hearing impaired condition; the least favorable reasonableness ratings were found in the $10 \mathrm{w}$ Position Level/hearing impaired condition (see Table 3 ).

The ANOVA performed for the honor scale also revealed a significant main effect for Position Level, $F(1,373)=$ $15.81, \underline{p}<.001$, where requests were more likely to be honored in the high Position Level condition than in the low Position Level condition, as shown in Table 2. There was also a significant interaction of Position level and Type of disability on the honor scale, $F(1,373)=4.88, \underline{p}<.05$. These results are presented in Table 4. As reported above, the interaction of Type of Disability and Positive Level indicated a greater mean difference of ratings in the Hearing Impaired conditions as compared to the Vision Impaired conditions (post-hoc comparisons were significant, $\underline{p}<.05)$.

Another item asked whether or not organizations should consider the type of a disability when deciding whether or not to make an accommodation for a disability. Results from the ANOVA on this item, shown in Table 5, revealed that when the cost of accommodation was high $(\$ 910)$ as opposed to medium $(\$ 510)$ or low $(\$ 110)$, subjects were significantly more likely to say that the type of disability should be 
considered when determining whether or not a request for an accommodation should be granted $\underline{E}(2,95)=7.65, \underline{p}<.01$.

Insert Table 5 About Here

Across all conditions, subjects rated cost for the voice synthesizer and vibrating signal system as slightly underestimated, although the differences between cost conditions was not significant. The means are presented in Table 6. Reliability Analyses, reported in Table 7, were performed for each of the four Employment of Peoples with Disabilities (EPDQ) scales. Cronbach's Alpha was found to be near .70 for all four scales; the reliability of the SADP was near .80 .

Insert Table 6 and 7 About Here

Correlations, reported in Table 8 , were computed between the EPDQ scales and other variables. The longer the subjects had been employed, the greater their sense of social responsibility toward disabled persons $(p<.01)$, the more positive were their attitudes were towards disabled persons $(\mathrm{p}<.001)$, and the more accepting they were of disabled persons in the work place $(\underline{p}<.01)$. Older subjects had more favorable attitudes toward disabled persons ( $D$ 
<.01). The greater the supervisory experience of subjects, the less positive were their general attitudes were toward disabled persons $(\underline{p}<.001)$. In addition, the SADP was correlated with scores on the GENATT and SOCRES scales.

\section{Insert Table 8 About Here}

\section{Hypothesis 3}

The hypothesis that favorable attitudes toward people with disabilities would be positively related to perceived reasonableness of accommodations and beliefs that accommodations should be honored was partly supported. Regressions of the SADP and the EPDQ scales on both REASREQ and HONREQ were performed. Only SOCRES was significantly related to the REASREQ and HONREQ scales, beta $=.15$ and $.20, \underline{t}=2.56$ and 3.48 , respectively, both $\mathrm{p}<.01$.

Across all conditions, the items listed most frequently by subjects as the primary factors that should be used to determine whether or not an accommodation request was reasonable were: cost of accommodation, position requirements, and accommodation type. These results are reported in Table 9.

Insert Table 9 About Here 


\section{DISCUSSION}

The study summarized above was conducted to investigate the impact of cost of accommodation, Position level, and attitudes toward disabilities on judgments of requests for accommodations. The results of this study revealed mixed findings for cost on the two dependent variables (REASREQ and HONREQ). There was no significant difference between the three cost levels; however, subjects listed cost as the primary factor that should be considered when determining the reasonableness of accommodations (see Table 9). Position level did have an effect on the dependent variables, while subjects' attitudes toward people with disabilities had modest correlations with their ratings.

First, the impact of cost (Hypothesis 1) will be considered. Reasons for the nonsignificant findings may include the following: First, manipulation of the cost levels may have been ineffective. The means ratings were high, indicating that subjects generally consider the requests to be reasonable and would honor them (see Table 1). If the range of cost levels was more extreme, the results for the manipulation of cost may have been more consistent with the open-ended responses. Note, however, that the costs used in the study were based on data from the Job Accommodation Network (see Appendix A). The sample of 96 subjects provided statistical power of 
.40 for a small effect size and power of .99 for a medium effect size (Cohen, 1969, p. 22). This level of power is acceptable for psychological research, and suggests that the sample size used was sufficient to detect any meaningful differences.

Results of the manipulation check indicated that subjects felt, across all conditions, that accommodation costs were reasonably accurate. (However, the voice synthesizer and the vibrating signal system were rated as slightly underestimated in the low cost level condition, see Table 6). These findings suggest that the manipulation of the cost levels was perceived as realistic, even though the range might not have been extreme enough. This lends further credence to the possibility of a problem with the manipulation of cost level.

Second, subjects may not be aware of the factors they used in rating the accommodations. Previous research, summarized by Lord (1985), suggests that decision makers are often incapable of accurately reporting which factors they use when making complex judgments. Subjects in this study may have reported that cost information was important even though they relied on other cues when rating the scenarios. Finally, null findings for cost may be due to the subjects' heightened awareness of the American's With Disabilities Act (1990). Specifically, there are widely- 
publicized demands on employers to provide accommodations to qualified employees and job candidates with disabilities. Employees in this study may have felt obligated to give "Politically Correct" responses, which might have caused ratings on the reasonableness and honor scales to be unusually high.

The second hypothesis predicted that Position Level of the employee would have a significant effect on "reasonableness" and "honor" request ratings. This hypothesis was supported. These results indicate that there is a greater perceived value for higher level (Executive) employees over lower level employees (Secretary), a finding which is not surprising in a capitalist society. The ADA was designed to afford equality to qualified individuals who have a disability and was not intended to create a disparity between various job classes and levels or gender. This study did not elicit from the subjects what gender they associated the position; however, gender stereotyping might have occurred. Since Executive Vice Presidents are typically male and secretaries are typically female, there exists the possibility that sex discrimination towards females occurred.

The above findings are important to employers for the following reason: the ADA (1990) intentionally prohibits accommodations to be weighed against the requestors salary, 
position level, or gender. According to the gender-bias and comparable worth literature, females hold more lower level positions and have lower salaries than their male counterparts (Ferraro, 1984). Employers must be aware of potential gender biases associated with position level that might be an underlying influence when addressing accommodation requests.

The third hypothesis was that general attitudes towards disabled individuals would have a significant effect on the perceived reasonableness of accommodations and on honoring such requests. Social responsibility (SOCRES) was significantly related to both the REASREQ and HONREQ dependent measures. However, the five other scales were not related to the measures. Reasons for the null findings may include the following: First, the recent passage of the Americans with Disabilities Act (1990) and the vast media and corporate attention it has received may have caused a heightened awareness of the issues examined in this study, resulting in a sensitivity towards disabled individuals. Second, most of the subjects were obtained through their organization's participation. Although participation by subjects was strictly voluntary and all test packets were anonymous, confidential, and available only to the primary researcher, subjects still may have felt the threat of disclosure of their responses. 
Third, the attitude scales were administered after the manipulation of cost. It is possible that subjects' responses to the attitude scales were influenced by the cost level presented to them, and that this procedure reduced the effectiveness of attitudes as covariates. However, administering the scales before the scenarios may have sensitized subjects to the purpose of the study and biased their ratings of the scenarios.

Finally, the relationship between attitudes and judgments of requests for accommodations may be weak. Even subjects who have strong attitudes in favor of or opposed to people with disabilities may make judgments of requests based on factors other than their own biases or stereotypes. Economic, social and organizational pressures may take precedence over belief systems.

The (unpredicted) interaction of cost with Type of disability was puzzling. Previous research (e.g., Combs \& Omvig, 1986) suggest that these disabilities are perceived in a similar fashion. In the present study, subjects gave more discrepant ratings across position levels for Hearing Impaired than they did for Vision Impaired. There is no previous research that provides an explanation for this effect. Perhaps the types of disabilities interacted with the specific positions used in the stimulus materials. For example, although hearing impairments are not among the most 
difficult disabilities to accommodate, a hearing impaired secretary might be at a greater disadvantage than would people in many other jobs - regardless of level.

This study identified some of the factors which appear to impact on the "reasonableness" of accommodations. Specifically, cost of accommodations, position requirements, and type of disability were listed by subjects as the factors they considered for reasonableness ratings. Position Level of the requestor and the social responsibility scale additionally was found to have a significant effect on dependent measures.

Future research should examine further the effects of cost of accommodations, including a greater range of cost levels. It is particularly important to use ranges of cost levels that are more extreme than those used above - as long as they are still perceived as reasonable. The effects of disability type, job classes, and gender effects should also be examined for disparate effects on the reasonableness of accommodations. Finally, future research should explore the effects of supervisor attitudes towards providing accommodations for their disabled subordinates. It was found that the greater the supervisory experience the less positive were attitudes toward people with disabilities.

In conclusion, I hope the results of this study provide insight for determining what "reasonableness accommodation" 
means under the ADA (1990). This study appears to be one of the first examinations of factors which may affect

"reasonable accommodation" conducted mainly in an

organizational setting. This author hopes it will foster future examination of factors which may contribute to assessments of "reasonable accommodation" under the ADA (1990). 
REFERENCES

Americans with Disabilities Act of 1990, 42 U.S.C 12101. Antonak, R. F. (1982). Development and psychometric analysis of the scale of attitudes towards disabled persons. The Journal of Rehabilitation Counseling, 13(2), 22-29.

Antonak, R. F. (1985). Construct validation and psychometric Analysis of the Scale of Attitudes Towards Disabled Persons (Technical Report No. 2). Durham, NH. University of New Hampshire Education Department. Antonak, R. F., \& Livneh, H. (1988). The measurement of attitudes toward people with disabilities. Illinois: Charles C. Thomas.

Bauman, M.K., \& Yoder, N.M. (1965). Analysis of employer interviews. In placing the blind and visually handicapped in clerical and service fields (VRA grant \#RD1901-S), Washington, DC: Department of HEW.

Berkeley Planning Associates (1982). A study of accommodations provided to handicapped employees for federal contractors (Contract No. J-9-E-1-0009). Berkeley, CA: Author

Bowe, F. (1984). U.S. Census and disabled adults: The fifty states and the District of Columbia. Fayetteville AR:Arkansas Rehabilitation Research and Training Center. 
Bowe, F. (1980). Rehabilitation America: Toward independence for disabled and elderly people. New York: Harper \& Row.

Bressler, R.B., \& Lacy, A.W. (1980). An analysis of the relative job progression of the perceptibly physically handicapped. Academy of Management Journal, 23, 132143 ,

Bureau of Labor statistics (1948). The performance of physically impaired workers in manufacturing industries. Labor Statistics Bulletin, No. 923. Chan, F. H., M-S., Ju, J. J., \& Lam, C. S. (1984). Factorial structure of the chinese scale of Attitudes Towards Disabled Persons: A cross-culture validation. International Journal of Rehabilitation Research, I, 317-319.

Cohen, J. (1969). Statistical power analysis for the behavioral sciences. New York: Academic Press. Combs, I. H., \& Omvig, C. P. (1986). Accommodation of disabled people into employment: Perceptions of employers. Journal of Rehabilitation, 52, 42-45. Cowen, E. L., Underberg, R. P., \& Verillo, R. J. (1958). The development of testing of an Attitude to Blindness Scale. Journal of Social Psychology, 48, 297-304. 
du Pont de Nemours \& Company (1973, winter). Reprinted from The Alliance Review, a Quarterly Publication of the National Alliance of Businessmen. Washington, DC:

President's Committee on Employment of the Handicapped. du Pont de Nemours \& Company (1982). Equal to the task: 1981 du Pont survey of employment of the handicapped. Wilmington, DE: Graphics Communication Division. Farina, A., \& Felner, R.D. (1973). Employment interviewer reactions to former mental patients. Journal of Abnormal Psychology, 83, 268-272. Ferraro, G. A. (1984). Bridging the wage gap: Pay equity and job evaluation. American Psychologist, 39, 1166-1170. Florian, V. (1978). Employers' opinions of the disabled person as a worker. Rehabilitation counseling Bulletin, 22, 38-43.

Foods, Inc. V. Iowa Civil Rights Commission, 318 N.W.2d 162 . (Iowa, 1982).

Fraser, S. L., \& Skipper, J. (1993). The development and validation of the Employment of People with Disabilities ouestionnaire. Manuscript in preparation. Goodyear, D.L. \& Stude, E.E. (1975). Work performance: A comparison of severely disabled and nondisabled employees. Journal of Applied Rehabilitation Counseling, $\underline{6}, 210-216$. 
Greenwood, R., \& Johnson, V.A. (1987). Employer perspectives on workers with disabilities. Journal of Rehabilitation, 53(3), 37-45.

Greer, W.E.R (1957, May). Statistical summary and analysis of experience in selective placement and follow up on cardiacs employed at Gillette safety Razor Company. Paper presented at the First Wisconsin Conference on Work and Heart, Marquette University, Milwaukee. Hartlage, L. C., \& Roland, P. E. (1971). Attitudes of employers towards different types of handicapped workers. Journal of Applied Rehabilitation Counseling, $\underline{2}, 115-120$.

Hartlage, L.C., \& Taraba, D. (1971). Implications of differential employer acceptance of individuals with physical, mental, and social handicaps. Rehabilitation Research and Practice Review, $\underline{2}(3), 45-48$. Hartlage, L.C., Roland, P., and Taraba, D. (1973). Perceptions of various types of disabilities by employers. In H.A. Moses \& C. H. Patterson (Eds.), Research readings in rehabilitation counseling. Champaign, IL: stripes.

Kagen, N. (1959). The development of and examination of correlates. Journal of Abnormal Psychology, 59, 44-55. 
Kelly, E.P., \& Aalberts, R. J. (1990). Americans with Disabilities Act: Undue hardship for private sector employers? Labor Law Journal, 41, 675-684.

Landy, D., \& Griffith, W.D. (1958). Placement of the emotionally handicapped: Employer willingness and counselor practice. Journal of Rehabilitation, 24(4), 17-18.

Lindsay, T. (1989-90). Discrimination against the disabled: The impact of the new federal legislation". Employee Relations Law Journal, 15, 234-249.

Lord, R. G. (1985). An information processing approach to social perceptions, leadership and behavioral measurement in organizations. In B. M. Staw \& L. L. Cummings (Eds.), Research in organizational behavior (Vol. 7, pp. 87-128). Greenwich, CT: JAI Press. Margolin, R. J. (1961). A survey of employer reactions to known former mental patients working in their firms. Mental Hygiene, 45, 110-115.

McKee, B. A. (1990). Planning For the disabled. Nation's Business, 78, 24-25.

Mithuag, D. E. (1980). Negative employer attitudes towards hiring the handicapped: Fact or fiction? Journal of Contemporary Business, $\underline{8}(4), 19-26$. 
Roessler, R., \& Bolton, B. (1984). Vocational rehabilitation of individuals with employability skill deficits:

Problems and recommendations. Fayetteville, AR:

Arkansas Research and Training Center in Vocational Rehabilitation.

Rothschild, C.S. (1970). The sociology and social

psychology of disability and rehabilitation. New York:

Random House.

School Board of Nassau County V. Arline. 683 F. Supp. 758

(D. Kan. 1987).

Shaller, E. H. (1991). "Reasonable Accommodation" under the Americans With Disabilities Act-what does It mean?. Employee Relations Law Journal, 16 (4), 431-451.

Simon, A.J. (1963). Disability doesn't count if the outlook is healthy. Personnel, 40, 57-64.

Susser, P.A. (1990). The ADA: Dramatically expanded federal rights for disabled americans. Employee Relations Law Journal, 16(2), 157-177.

Thornburgh, R. (1989). Hearings on the H.R. 2273 before the House committee on the Judiciary and the subcommittee on Civil and constitutional Rights, 101st cong., 2nd Session.

Treadwell V. Alexander, 707 F.2d 473 (11th Cir. 1983). 
Wacker, C. H. (1976). Breaking the competitive employment barrier for blind people. Journal of Rehabilitation, 42, 28-31. Wallace V. Veterans Administration, 683 F. Supp. 758 (D. Kan. 1988).

Williams, C.A. (1972). Is hiring the handicapped good business? Journal of Rehabilitation, $38, \underline{2}, 30-34$. 
Table 1

ANOVA Results for Dependent Variables

Source

Reasonableness of Request

Cost Level (Cost) 2

Type of Disability (Type)

Position Level (Level)

Cost $\times$ Type

cost $\mathrm{x}$ Level

Type $\mathrm{x}$ Level

Cost $x$ Type $x$ Level

Honor Request

Cost Level

Type of Disability

Position Level

Cost x Type

Cost $x$ Level

Type x Leve1

cost $x$ Type $\mathrm{x}$ Level
DF

2

1

1

2

2

1

2

2

1

1

2

2

1

2

$\underline{\text { MS }}$

F

.74

.00

11.82

$16.98 * *$

.22

.32

.00

.00

3.68

5.28 *

1.75

2.51

$\begin{array}{rrc}1.04 & 1.30 \\ 1 & .06 & .78 \\ 2 & 11.78 & 15.81 * * \\ 1 & .27 & .37 \\ 2 & 3.64 & 4.88 * \\ 1.87 & 2.52\end{array}$

$* * \mathrm{p}<.01$

$* \mathrm{p}<.05$ 
Table 2

Cell Means for the Main Effects of Position Level on

"Reasonableness" Ratings and on "Honor Request" Ratings

Dependent Variables

Position Levels

REASREQ

HONREQ

Secretary (low)

$3.66(\underline{n}=188) \quad 3.60 \quad(\underline{n}=188)$

Executive VP (high)

$4.02 \quad(\underline{n}=186) \quad 3.95 \quad(\underline{n}=186)$

* Means significantly higher in EVP condition $F(1,373)$,

$\underline{p}<.000$ 
Table 3

Cell Means for the Two-way Interaction Between Position

Level and Disability Type on the "Reasonableness of

Accommodations" Scale

Position Level (means)

Disability type Secretary (low) Executive VP (high)

Vision impaired $3.76 \quad(\underline{n}=94) \quad 3.91 \quad(\underline{n}=94)$

Hearing impaired $3.56 \quad(\underline{n}=94) \quad 4.12 \quad(\underline{n}=92)$ 
Table 4

Cell Means for the Two-way Interaction Between Position

Level and Disability Type on the "Honor Accommodation" Scale

Position Level (means)

Disability type Secretary (low) Executive VP (high)

$\begin{array}{lllll}\text { Vision impaired } & 3.68 \quad(\underline{n}=94) & 3.84 \quad(\underline{n}=94) \\ \text { Hearing impaired } & 3.51 \quad(\underline{n}=94) & 4.07 \quad(\underline{n}=92)\end{array}$


Table 5

Group Means for Consideration of Disability Type when

Evaluating an Accommodation Request

Cost

$\underline{n}$

Means

Low

36

3.22

Medium

31

3.13

High

29

3.96

* The high cost level condition was significantly different from the medium and low cost levels, $F(2,95), p<.001$. 
Table 6

Mean Responses for Accommodation Estimates

\section{Cost Levels}

ACCOMMODATION

Low Medium High

Pressure-sensitive Floor Mat

2.60

2.88

2.97

Voice Synthesizer

2.00

2.46

2.24

Vibrating Signal system

2.09

2.70

2.59

Telephone Amplifier

2.80

3.20

3.41

* Slight underestimates for the Voice Synthesizer and Vibrating signal system. 
Table 7

Reliability of the Four EPDQ Scales and of the SADP

Item Total statistics

$\underline{\text { Scale }}$

$\underline{n \text { cases }}$

n items

alpha

GENATT

80

13

.69

SOCRES

83

9

.71

WFINT

79

9

.70

ORGRESP

83

9

.64

SADP

81

24

.79 
Table 8

Correlations between EPDQ Scales and other Variables

\section{EPDQ Scale}

General Social Workforce Organizational

Attitudes Responsibility Integration Responsibility

\begin{tabular}{lcccc}
\hline Age & .10 & -.09 & $-.31 *$ & .20 \\
Gender & .16 & .06 & $.33 *$ & .16 \\
Voting & .15 & .09 & .16 & .26 \\
$\begin{array}{l}\text { Employment } \\
\text { Status }\end{array}$ & .13 & $.31 *$ & $.31 *$ & .13 \\
$\begin{array}{l}\text { Years } \\
\text { Working }\end{array}$ & .10 & -.01 & -.23 & -.18 \\
$\begin{array}{l}\text { Supervisor- } \\
\text { Status }\end{array}$ & .04 & .23 & .07 \\
SADP Total & $.53 * *$ & $.44 *$ & -.26 & .05 \\
\hline
\end{tabular}

Note: $\underline{\mathrm{n}}=66$ 
Table 9

Frequency of Primary Factors used to Determine

Reasonableness of Accommodations

Condition cost $\begin{gathered}\text { Position } \\ \text { Requirements }\end{gathered} \quad \begin{gathered}\text { Accommodation Missing } \\ \text { Type }\end{gathered}$

Vision Impaired

$\begin{array}{lrrrr}\text { Secretary } & 18 & 9 & 11 & 17 \\ \text { Exec. VP } & 14 & 12 & 6 & 28\end{array}$

Hearing Impaired

$\begin{array}{lcccc}\text { Secretary } & 13 & 14 & 2 & 35 \\ \text { Exec. VP } & 12 & 7 & 8 & 32 \\ \text { Total } & 52 & 42 & 27 & 112\end{array}$

* All other factors had a total frequency less than 27 across all conditions. 


\section{APPENDIX A}

COST OF ACCOMMODATIONS

Percent of Accommodations

$31 \%$

$19 \%$

19\%

$19 \%$

$11 \%$

LESS THAN 1\%
Cost

NO $\cos T$

$\$ 1-\$ 50$

$\$ 50-\$ 500$

$\$ 500-\$ 1000$

$\$ 1000-\$ 5000$

OVER $\$ 5,000$

Note: Costs are based on the Job Accommodation Network's suggestions to employers who ask for assistance. 
APPENDIX B

REASONABLE ACCOMMODATION

RESEARCH PACKET

RESEARCHER

COMPANY NAME

SUBJECT NUMBER (pre-assigned)

Introduction and Purpose of Study

This study is being conducted as thesis research by a graduate student in Psychology at Florida International University. As participants and subjects in this study, you will be asked to complete the following:

- Background Information (Demographics)

- Evaluate Case Scenarios

- An Attitude Survey

The purpose of the study is to assess accommodations for jobs that will make employment more accessible for the disabled.

\section{CONFIDENTIALITY}

All responses obtained in this study are completely anonymous. Results of the scale and questions used will be summarized and reported as group data. No individual responses will be presented. Furthermore, only the principal investigators of this study will have access to information provided by this study.

Your participation in this study is voluntary. You may withdraw from the study at any time without penalty. 


\section{BACKGROUND INFORMATION}

Please provide the following information:

(1) What is your age?

(2) What is your ethnic origin? Black Hispanic White, non-Hispanic Asian or Pacific Islander American Indian or Alaskan Native

(3) Are you male or female? $\longrightarrow \mathrm{M} \longrightarrow \mathrm{F}$

(4) Are you a registered voter? Yes No

(5) Are you employed...... Full-time
Part-time
Unemployed

(6) What is the total number of years that you have worked (full-time and part-time combined)? yrs.

(7) Are you currently or have you previously been in a position where you supervise/manage others? Yes No

(8) What type of job do you now hold?
Clerical Personnel/Human Resources
- Sales Healthcare Skilled Trade/Semi-Skilled Legal/ - Paralegal
-
- Skilled T Professional (other than Health, Law, Ed.)

(9) Do you consider yourself as having a functional impairment (disability) which limits your capacity to perform certain jobs? No Yes

\section{REQUEST FOR ACCOMMODATIONS}

Please read the following case scenarios describing requests for accommodations by employees with disabilities. Be sure to read each job description and description of accommodation prior to answering the questions that follow each scenario. 
II. VIBRATING SIGNAL SYSTEM (Sample Scenario)

POSITION TITLE: Secretary

DESCRIPTION OF JOB DUTIES:

Schedule appointments; provide information to callers: organize and maintain files; proficient in Word Perfect 5.1; operate various office-type machines; except dictation: greet clients; operate a 9-1ine switchboard; possess strong inter-personal skills.

\section{FUNCTIONAL LIMITATION ACCOMMODATED:}

Hearing Impaired (partial/complete)

\section{DESCRIPTION OF ACCOMMODATION:}

This system converts auditory alarm signals into vibrations that can be felt. It consists of a transmitter which has 5 input channels and a vibratorreceiver which is worn on the body (in a pocket or fastened to clothing). Detectors can be placed in as many as 5 different locations ( $i, e$ by the telephone, doorbell, reception area). The different locations and thus different alarms are discriminated by unique vibration patterns of the 5 channels.

ESTIMATED COST: $\quad \$ 110.00$

PLEASE ANSWER THE FOLLOWING QUESTIONS.

1 This request for accommodation is "reasonable"?

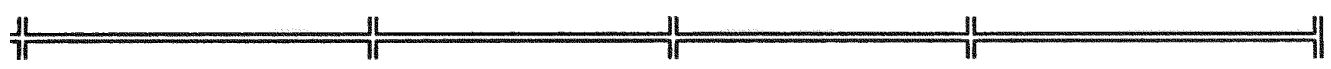

Strongly Disagree Uncertain Agree
Disagree $\quad \begin{gathered}\text { Strongly } \\ \text { Agree }\end{gathered}$

2 The organization should honor the request for accommodation in this case?

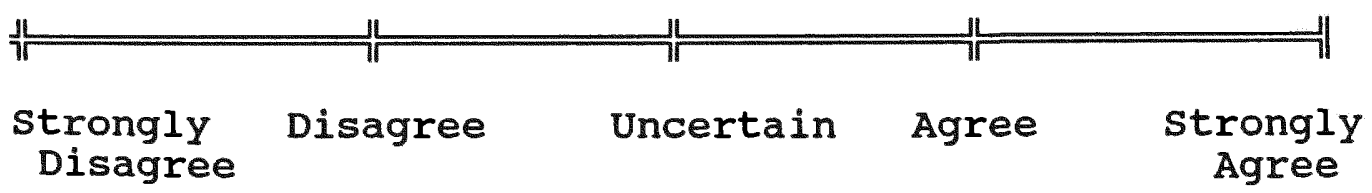

3 List the factors you considered in deciding if this request for an accommodation was reasonable. 
III. QUESTIONNAIRES

\section{ATTITUDES TOWARDS DISABLED PERSONS SCALE [FORM-O]}

Directions:

Mark each statement in the left margin according to how much you agree or disagree with it. Please mark every one. Write $6,5,4$, or $3,2,1$, depending on how you feel in each case.

$\begin{array}{llll}6 & \text { I agree very much } & \text { REY } & \\ 5 & \text { I agree pretty much } & 3 & \text { I disagree a little } \\ 4 & \text { I agree a little } & 2 & \text { I disagree pretty much } \\ & & 1 & \text { I disagree a little }\end{array}$

1 Parents of disabled children should be less strict than other parents.

2 Physically disabled persons are just as intelligent as non-disabled ones.

3 Disabled people are usually easier to get along with than other people.

4 Most disabled people feel sorry for themselves.

5 Disabled people are the same as anyone else.

6 There shouldn't be special schools for disabled children.

7 It would be best for disabled persons to live and work in special communities.

8 It is up to the government to take care of disabled persons.

9 Most disabled people worry a great deal.

10 Disabled people should not be expected to meet the same standards as non-disabled people.

11 Disabled people are as happy as non-disabled ones.

12 Severely disabled people are no harder to get along with than those with minor disabilities.

13 It is almost impossible for a disabled person to lead a normal life. 
14 You should not expect too much from disabled people.

15 Disabled people tend to keep to themselves much of the time.

16 Disabled people are more easily upset than nondisabled people.

17 Disabled persons cannot have a normal social life.

18 Most disabled people feel that they are not as good as other people.

19 You have to be careful what you say when you are with disabled people.

20 Disabled people are often grouchy.

EMPLOYMENT OF PEOPLE WITH DISABILITIES QUESTIONNAIRE

This questionnaire concerns your attitudes and beliefs about issues related to the employment of people with

disabilities. Please rate each of the following statements based on the extent to which you agree or disagree with it. Use the following scale for your ratings:

$$
\begin{aligned}
& 5 \text { - strongly Agree } \\
& 4 \text { - Agree } \\
& 3 \text { - Undecided } \\
& 2 \text { - Disagree } \\
& 1 \text { - strongly Disagree }
\end{aligned}
$$

1. Employees with disabilities are as productive and as efficient as are employees who do not have disabilities.

2. Employees with disabilities have a difficult time adjusting to the social aspects of the workplace.

3. I would be comfortable working with an individual who has a history of mental illness.

4. Pre-employment tests given by organizations unfairly discriminate against people with disabilities. 
5. Employees without disabilities should make a greater effort to get along with co-workers who have disabilities.

6. Having an individual who has a disability work for me as a secretary or an assistant would defeat any attempts of mine to work efficiently.

7. A co-worker who has a disability would just add to my work load and to the work load of other employees who do not have disabilities.

8. It would be a major inconvenience if my work schedule had to be changed in order to accommodate a co-worker who had a disability.

9. I would be comfortable working with an individual who is missing an arm or leg.

10. Employees with disabilities tend to be overly dependent on others and tend to place frequent demands on the organization.

11. Supervisors tend to promote and to give good evaluations to people with disabilities because they feel sorry for them.

12. People with disabilities are slow workers.

13. Organizations hire people with disabilities because they fear lawsuits.

14. People with disabilities are absent from work more often than are individuals who do not have disabilities due to their greater medical needs.

15. Employees with disabilities should have the same opportunities for advancement as do employees without disabilities.

16. I would find it very difficult to work with an individual who is HIV positive or who has the AIDS virus.

17. Organizations should not make a special effort to hire people with disabilities unless there are laws that make them do so. 
18. Organizations should be concerned with profit and productivity, not with social issues such as opportunities for people who have disabilities.

19. Individuals with a history of mental illness can be successfully placed in management or supervisory positions.

20. People with disabilities should not be placed in positions that require transporting people or that affect public safety.

21. Individuals with a history of mental illness should not hold jobs that involve dealing with children.

22. Organizations should not use any pre-employment tests to evaluate people with disabilities.

23. Individuals who have any type of infectious or communicable diseases do not belong in the work place.

24. Organizations should do whatever it takes to educate employees who do not have disabilities about the value of hiring people who have disabilities.

25. Organizations tend to view hiring a person with a disability as an added cost instead of as a benefit.

26. Individuals who are HIV positive or who have the AIDS virus have a disability and should not be discriminated against in the workplace.

27. Employees with disabilities should receive additional training and extra time to learn their jobs.

28. Employees with disabilities are less flexible and adaptable than are employees who do not have disabilities.

29. Individuals with a history of mental illness or retarded individuals can be successfully placed in entry-level or unskilled positions. 
30. Employees with disabilities can handle job pressures and stress as well as can employees without disabilities.

31. Organizations should do whatever it takes to accommodate employees with disabilities no matter what the cost.

32. Organizations should provide employees with disabilities with additional supervision or support staff.

33. It seems that organizations tend to hire people with disabilities only when it benefits their public image.

34. Organizations should hire individuals who are disfigured or scarred even for positions that call for dealing with customers and the public.

35. Organizations should have employee assistance programs for the rehabilitation of alcohol or drug abusers.

36. I would change my job duties to accommodate a coworker who has a disability.

37. Small businesses should not have to make costly changes to accommodate employees with disabilities.

38. An individual with a disfigurement of some kind would be easier to work with than would a mildly retarded individual.

39. Organizations should make all existing facilities readily accessible to and usable by people with disabilities.

40. Organizations should modify work schedules to accommodate people with disabilities. 